\title{
AOR
}

Selected Papers of \#AolR2018:

The $19^{\text {th }}$ Annual Conference of the

Association of Internet Researchers

Montréal, Canada / 10-13 October 2018

\section{A HAUNTOLOGICAL ANALYSIS OF DIGITAL MEMORIALIZATION OF THE DEAD}

Carrie O'Connell

University of Illinois at Chicago

The cultural ways in which we memorialize the dead are changing in the digital age. While traditional forms of memorial like wakes, funerals, or altars of offering still persist in Western culture, newer forms of digital memorialization have emerged with the rise of social networking sites. Facebook and other social platforms now allow pages of the deceased to remain active, controlled by immediate family of the deceased person, as a sort of memorialization or "electronic wake," (Stokes, 2011). Emerging research on user interaction with memorial pages on social networking sites (Massimi and Charise, 2009; Kern, Forman, and Gil-Egui, 2012; Goldschmidt, 2013; Bouc, Han, and Pennington, 2015) suggests that while these pages do serve as artefacts of the dead much the same way headstones in a graveyard serve as static memorials, these interactive pages also represent a digital continuation of the relationship between the living and dead, as one-sided as that relationship may be.

The overall goal of the author is to examine the evolution of the materiality of memorialization and investigate how our human connection with death has changed as our media tools have become untethered from tangible artefact. As is often the case, the history of the evolution of media tools may offer insight. During the 19th century-arguably the last time an epochal evolution of media technology occurred--fascination with ghost-themed theatre, poetry, and literature (not so) coincidentally paralleled a rise in new technologies that forever changed both the way we preserve and chronicle our human existence, as well as the manner in which we socially engage with our fellow humans, mass culture, and the artefacts of that mass society due to those new technologies. Today, the advancement of virtual reality technologies and artificial intelligence, as well as modern controversies over the ethics of "preserving" life after death via social network profiles have brought humankind to the precipice of change once again.

Suggested Citation (APA): O'Connell, C. (2018, October 10-13). A Hauntological Analysis of Digital Memorialization of the Dead. Paper presented at AolR 2018: The $19^{\text {th }}$ Annual Conference of the Association of Internet Researchers. Montréal, Canada: AoIR. Retrieved from http://spir.aoir.org. 
This paper will argue that, similar to the technological epochal change and subsequent impact on human interaction with tangible media artefacts that occurred in the 19th century, we are once again undergoing a cultural and spiritual catharsis brought on by evolving technology that not only threatens to supplant our understanding of what it means to be human, but also what it means to be posthuman. This paper will explore three particular lessons gleaned from the correlation between the rise of media technology and a cultural fascination with ghosts in the 19th century:

1. Advances in media technologies provided new avenues for dyadic communication between living beings, yet forced a re-evaluation of concepts like distance and temporal synchronicity in regards to those relationships.

2. Advances in media technology change our human relationship with spectral beings, and therefore death itself.

3. Spectral images that live through media deceive the viewer as a form of sleight of hand: on a superficial level, new technologies promise the viewer an extension of life in simulacrum, though this disembodied replication lacks beingness.

To explore the links between media, human relationships, and the spectral plane, and how those links might be revelatory in an age of digital media, a hauntological examination of these questions will be endeavored.

The basic premise of hauntology, a clever merge of haunting and ontology derived by Jacques Derrida (1993), is that an idea, once tangibly realized — even if just through written form-and, therefore, made real in the cultural zeitgeist, is never truly extinguished. Like a spirit that lingers after death, the cultural lessons of the past linger anywhere from casual conversation to formal canon, enshrined in our cultural consciousness through tangible media which capture their written, visualized, and / or digital form. Derrida's hauntology derives from the ontological quest to articulate the nature of being, yet with the added perspective that everything that exists might not have ever lived, and nothing which is past ever really quite dies. This is no more so true than in our heavily mediated age in which written documents, photographs, film, and the Internet are able to capture, record, store-and, as will be discussed-even replicate beingness in physical form. In an age where simulacra parade as true being, and cultural memory of events as accepted historical provenance, perhaps our human reality cannot be sufficiently quantified or qualified in temporal terms.

Examining the historical links and patterns between eras will only get us so far in our quest to understand the current impact of technology on humankind. In our current trans-epochal stage, "something is changing, something different is emerging--we can all feel it, and we are trying to articulate is," (Kochhar-Lundgren, 2005, p. 194). By embracing a hauntological perspective we may very well abandon the need to find a causal relationship between life and the afterlife--one grounded in our need to articulate (or, find meaning). In the context of the philosophy of being, hauntology upends the notion that the material and ideal planes represent a fixed binary of opposites. Because of the presence of specters - be they the traces of ideology never fully realized or the trauma of past lives encoded within living Egos-we must reckon with the idea that being, or lack of being, may also represent neither what is ontologically material or ideal. Perhaps there is a new mode of being - one that has yet to be fully understood. 
It is in the promise of a new perspective-a new way of understanding our own human existence-that hauntology proves an enticing theory from which to analyze our modern cultural fascination with and relationship to death.

\section{References}

Bouc, A., Han, S., \& Pennington, N. (2016). "Why are they commenting on his page?": Using Facebook profile pages to continue connections with the deceased. Computers in Human Behavior, 62635-643. doi:10.1016/j.chb.2016.04.027

Derrida, J. (1994) Specters of Marx: The State of the Debt, the Work of Mourning, and the New International. New York: Routledge.

Goldschmidt, K. (2013). Thanatechnology: Eternal Digital Life After Death. Journal of Pediatric Nursing, 28(3), 302-304. doi:10.1016/j.pedn.2013.02.021

Kern, R., Forman, A. E., \& Gil-Egui, G. (2013). R.I.P.: Remain in perpetuity. Facebook memorial pages. Telematics \& Informatics, 30(1), 2-10. doi:10.1016/j.tele.2012.03.002

Kochhar-Lindgren, G. (2004). TechnoLogics: Ghosts, the incalculable, and the suspension of animation. Albany: State University of New York Press.

Massimi, M., \& Charise, A. (2009, April). Dying, death, and mortality: towards thanatosensitivity in $\mathrm{HCl}$. In CHI'09 Extended Abstracts on Human Factors in Computing Systems (pp. 2459-2468). ACM

Stokes, P. (2012). Ghosts in the machine: Do the dead live on in Facebook? Philosophy \& Technology, 25(3), 363-379. doi:10.1007/s13347-011-0050-7. 